\title{
New morphological aspects of cephalodium formation in the lichen Lobaria pulmonaria (Lecanorales, Ascomycota)
}

\author{
Carolina CORNEJO and Christoph SCHEIDEGGER
}

\begin{abstract}
Cephalodia were investigated on young and mature thalli of Lobaria pulmonaria. Cephalodia originate from contact between hyphae and cyanobacteria on the upper or lower cortex or, less frequently, in the apical zone. Young thalli were found to associate with cyanobacteria even in the anchoring zone. Cephalodia formed on the young thalli or the anchoring hyphae share the same phenotypic characteristics. In spite of being composed of paraplectenchymatous hyphae, the cortex of mature thalli preserves a considerable plasticity, enabling the formation of cephalodia. The cyanobacterial incorporation process begins with cortical hyphae growing out towards adjacent cyanobacterial colonies, enveloping them and incorporating them into the thallus. The incorporation process is the same on the upper and the lower cortex. Early stages of cephalodia are usually found in young lobes, whereas in the older parts of the thallus only mature cephalodia are found.
\end{abstract}

Key words: cephalodia, cephalodiate lichen, Nostoc, tripartite lichen

Accepted for publication 26 June 2012

\section{Introduction}

There has been heated debate over the nature of cephalodia for more than 50 years. Forsell (1884) was the first to propose that cyanobacteria are incorporated actively by the mycobiont and do not penetrate into the thallus by themselves. Thus, in contrast to other contemporary authors, he considered cephalodia to be part of the symbiotic phenotype and not parasitic (Winter 1877; Moreau 1921; Kaule 1932). Forsell (1884) defined cephalodia as formations of the lichen thallus which contain algae of a different kind to those found in the algal layer, and which evolve by the interaction of hyphae with these algae. Today it is generally accepted that a cephalodium is a specialized protuberance, a gall-like structure of the vegetative thallus that includes a cyanobacterium in a symbiotic relationship (Jordan 1970; Jahns 1988; Paulsrud et al. 1998; Honegger 2001).

C. Cornejo and C. Scheidegger: Swiss Federal Institute for Forest, Snow and Landscape Research WSL, 8903 Birmensdorf, Switzerland. Email: carolina.cornejo@wsl.ch
Cephalodia were first classified by Nylander (1868) as epigenic, hypogenic or endogenic. This categorization assumes that cephalodia are found where they originated. Winter (1877) and Forsell (1884), however, noticed that cephalodia, which form on the lower cortex, could grow into the thallus. This means that the thalloid position of cephalodia does not necessarily correspond to their point of origin. Later authors followed Nylander's classification, with diverse modifications related to the species studied and without the misleading term endogenic. Jordan (1970) called a superior cephalodium a protuberance located on the upper surface, and the author used inferior for a cephalodium situated on the lower cortex. Recent works refer to cephalodia simply as internal, if located in the medulla, or external, if found on the upper or lower cortex (Henssen \& Jahns 1974; Rikkinen et al. 2002).

During the 19th and early 20th centuries, a considerable amount of research was carried out on developmental questions of cephalodia. Although Winter (1877) was an advocate of the parasite-hypothesis of cephalodia, he was the first lichenologist to document 
in detail the fungal incorporation of cyanobacteria into the thallus. In a study on the cephalodia of Lobaria linita (Ach.) Rabenh., Winter reported that hyphae of the upper or lower cortex grow towards adjacent cyanobacteria colonies and expand between the blue-green cells enveloping them. Forsell (1884) supported this developmental process but interpreted this association as a symbiotic relationship. Observations of Hue (1904), Moreau (1921) and Kaule (1932) on cephalodia of the Lobariaceae are concordant with these authors. In contrast, Jordan (1970) found that cephalodia of the genus Lobaria can only begin formation on the lower cortex. He understood superior cephalodia as erumpent bulbs that have grown through the thallus from the lower to the upper cortex.

In cephalodia-forming lichens, the functional photosynthetic partner is a eukaryotic green alga, while the prokaryotic blue-green photobiont fixes atmospheric nitrogen which is used by both symbionts. Cyanobacteria in cephalodia have been shown to have higher heterocyst frequencies and higher rates of nitrogen fixation than those in bipartite cyanolichens (Rai \& Bergman 2002). This nitrogenfixing ability of cyanobacteria has two effects on the lichen ecology. On the one hand, lichen species hosting $\mathrm{N}_{2}$-fixing cyanobacteria symbionts show higher organic nitrogen concentrations compared to species without cyanobacteria (Lawrey 1986). Consequently, Büdel \& Scheidegger (1996) conclude that cyanobacterial lichens may have an advantage to colonize special ecological niches, such as extremely oligotropic habitats. On the other hand, in oldgrowth forests with high lichen biomass, decomposition of cyanobacterial lichens may contribute significant amounts of organic nitrogen to the forest ecosystem (Green et al. 1980; Guzman et al. 1990; Knops et al. 1991; Antoine 2004; Knowles et al. 2006; Benner et al. 2007).

Although in recent years significant research has been done on the interactions between mycobiont and photobiont (Honegger 2001), less is known about the impact of both photobionts on the fungal phenotype. It is evident that, on the same thallus, the mycobiont responds with different morphological structures to the relationship with both photobionts. In the case of the foliose lichen Lobaria pulmonaria (L.) Hoffm., the green alga fill the dominant thallus and are situated in a layer directly below the cortex in the upper medulla, whereas the Nostoc cells are found in cephalodia, which are attached to distinct parts of the thallus. In photosymbiodemes, composed of greenalgal and cyanobacterial sectors in the same thallus, the cyanobacterial area is more appressed to the trunk in contrast to the greenalgal parts. This morphological arrangement may be caused by the ecological need of the blue-green photobionts for liquid water to be photosynthetically active (Green et al. 2002). A direct physical contact has never been observed between cyanobacteria and green algae (Rai \& Bergman 2002).

A further aspect of the tripartite life form is the role that cyanobacterial nitrogenous triggers may play in morphogenesis. StockerWörgötter (1994, 1995, 2001) found in resynthesis experiments of different photosymbiodeme species that the growth of a new thallus of Peltigera leucophlebia (Nyl.) Gyelnik is initiated from a prothallus with Nostoc as the exclusive photobiont and young green lobes grow either on a cyanobacterial layer or on cyanobacterial lobules only. Similar experiments with Lobaria fendleri (Tuck. \& Mont.) Lindau revealed that the green-algal stages developed independently of the presence of cyanobacteria, but stopped growing after one year. Sundberg et al. (2001) removed cephalodia from Nephroma arcticum (L.) Torss. and Peltigera aphtosa (L.) Willd. during four summer months and investigated the relationship between growth and nitrogen concentrations. It might be that cephalodia did not influence the lichen weight gain, the thallus growth on an area basis was significantly inhibited. Observations from Placopsis pycnotheca I. M. Lamb, a primary colonizer of bare soils, showed that its hypothallus formed cephalodia before formation of the typical squamules containing the green-algal photobiont (De los Ríos et al. 2011). 
Cephalodia are found in about 520 species distributed through 21 genera (Hawksworth \& Hill 1984). They occur regularly in the Stereocaulaceae and in the genera Psoroma and Placopsis, and they are also found frequently in the Peltigeraceae and Lobariaceae (Henssen \& Jahns 1974). It has been shown that cephalodia evolved independently in lichens representing different systematic groups (Rikkinen et al. 2002; Lohtander et al. 2003; Rikkinen 2009). Amazingly, convergent evolution has led to similar thallus structures in distantly related lichen-forming fungi. The switch from a bipartite cyanolichen to a tripartite green-algal lichen forming cephalodia, or vice versa, has occurred within Nephroma and Peltigera more than once (Miądlikowska \& Lutzoni 2000, 2004; Lohtander et al. 2003).

The present work, looking at the process of cyanobacterial incorporation into the lichen Lobaria pulmonaria, focuses on two aspects. First, we address the question as to whether juvenile thalli associate with cyanobacteria. Second, we put emphasis on the different patterns of cephalodium formation.

\section{Materials and Methods}

\section{Sampling}

Because Lobaria pulmonaria is a threatened species in Switzerland (Scheidegger et al. 2002), the study had to be limited to a small number of specimens. Hence, the present study is based on observational data that were not used for statistical evaluation. The main specimen selection criterion was the development stage of young thalli. We chose young thalli that had scarcely risen from successfully attached soredia or isidioid soredia, growing on moss or directly on tree bark. Nine young thalli and five mature thalli growing on the bark of Acer pseudoplatanus L. in an upper mountain mixed forest in the Wägital valley, Switzerland, $\left(47^{\circ} 04^{\prime} 70^{\prime \prime} \mathrm{N}\right.$, $8^{\circ} 56^{\prime} 40^{\prime \prime} \mathrm{E}$ ) were collected. All specimens were air dried and subsequently processed for microscopic analysis within a few days of collection.

\section{Microscopy}

The external morphology and hand-cut sections were examined with a macroscope (Wild AG, MDG 17) and photographed using a Wild MPS 51 camera (T MAX 100 or Ektachrom 64, Kodak).
Specimens were cleaned thoroughly in tap water, cut into small strips and immediately fixed in a $2 \%$ glutaraldehyde phosphate buffer solution, $\mathrm{pH} 7 \cdot 1$, for $2 \mathrm{~h}$ at room temperature. To wet the gas-filled cavities in the medulla, flasks were evacuated carefully until the specimens were completely saturated by the solution. After washing the specimens twice in phosphate buffer for $1 \mathrm{~h}$ each, they were dehydrated in a water-ethanol series (30, $50,70,90$ and $2 \times 100 \%$ ethanol puriss, $1 \mathrm{~h}$ each series). After dehydration, the specimens were infiltrated with a 1:1 ethanol-methacrylate mixture (Technovit, Kulzer) first for $4 \mathrm{~h}$, then for $6-12 \mathrm{~h}$, followed by incubation in pure methacrylate (hardener 1) for 6-12 h. Subsequently specimens were embedded in pure Technovit (hardener 2). Polymerization was completed after 30 min at room temperature. Embedded specimens were sectioned at $2-3 \mu \mathrm{m}$ and stained unspecifically for 1 min with a modified Lee's mixture ( $R$. Honegger, pers. comm.). Stained sections showed pink and dark blue cortices, pink medullar hyphae, red-coloured green algal cells, and violet cyanobacteria. Stained and dried specimens were mounted in Entellan (Merck), examined with an Aristoplan Photomicroscope (Wild Leitz AG) and photographed using a Wild MPS 48 camera (T MAX 100 or Ektachrom 64, Kodak).

\section{Results}

\section{Cephalodia in young thalli}

Soredia and isidioid soredia breaking off may disperse to a suitable substratum and develop into new thalli (Scheidegger 1995). In this case, the growing diaspore produces first anchoring hyphae, then becomes flattened and thereby shifts the algal cells to one layer. The specimens collected were successfully attached to young thalli that had already begun to enlarge (Fig. 1A); three of them had also started to divide into lobules (Fig. 1B).

All young thalli collected were examined and five had formed cephalodia; in only two of these the cephalodia were visible as external protuberances, which lay on the distal, unstratified zone belonging to the former diaspora, or on the apical thallus margin (Fig. 1B). In sections, internal cephalodia were also observed (Fig. 1D). It is noteworthy that cephalodia were developed also with Nostoc cells that were not in direct contact with the lower cortex but with the anchoring hyphae (Fig. 1C). 

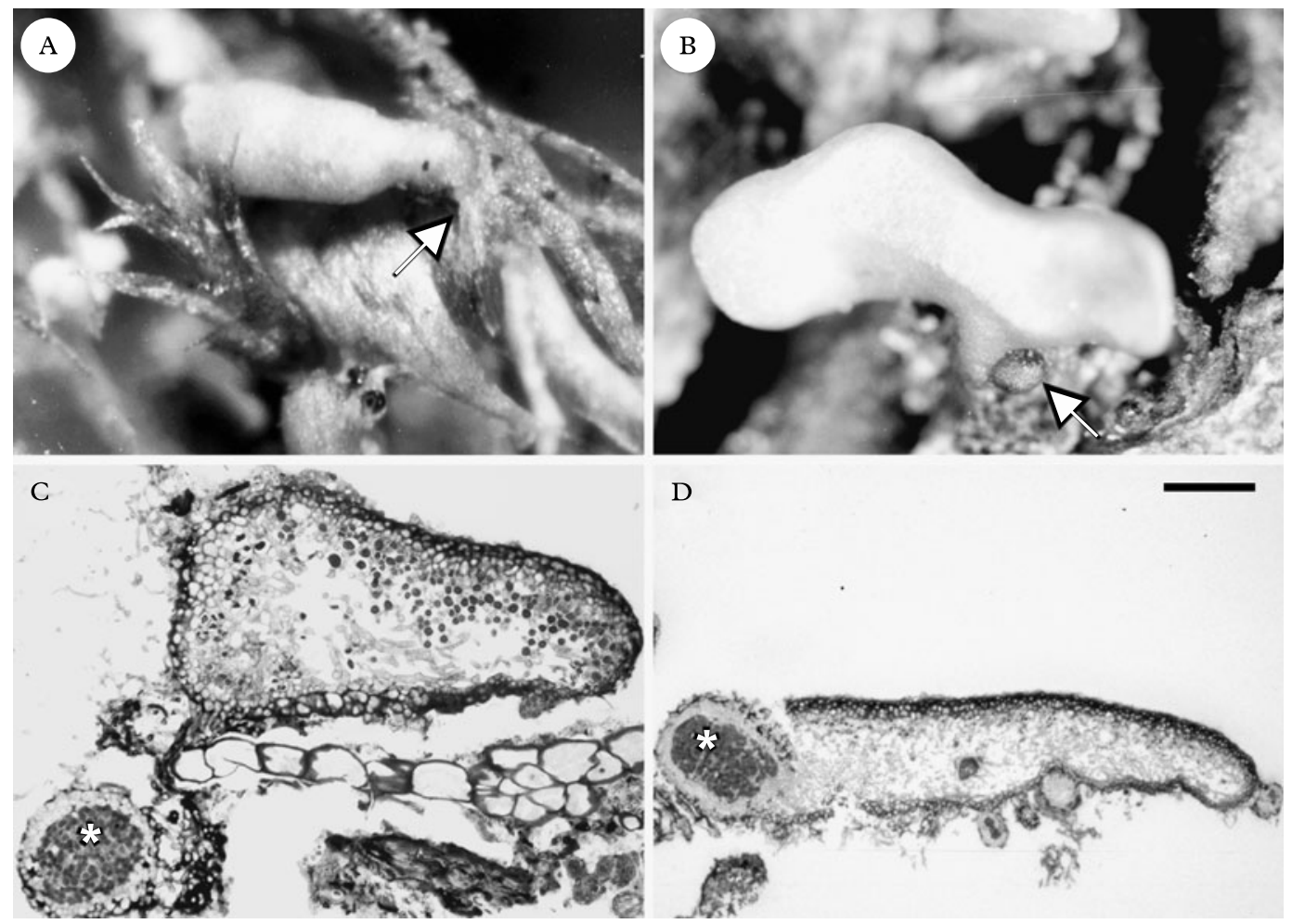

$\mathrm{D}$

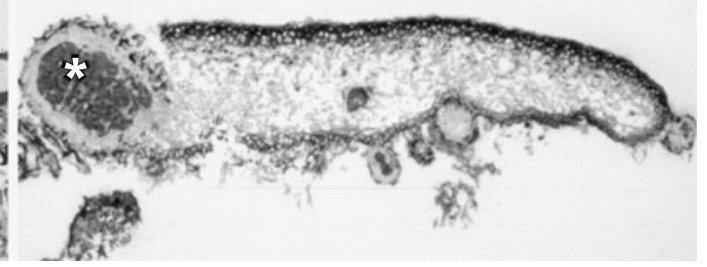

FIG. 1. Photographs and light micrographs of juvenile L. pulmonaria thalli. A, a successfully anchored young thallus that started to grow in the apical zone. Note the anchoring hyphae (arrow); B, young thallus anchored on tree bark with an external cephalodium on the distal part of the former isidioid soredium (arrow); C, the young thallus in (A) on a moss leaf has formed a cephalodium with Nostoc cells (asterisk) that were in contact with the anchoring hyphae only; D, this young thallus formed external, internal and apical cephalodia. Note the cephalodium in the distal zone (asterisk). Scales: $\mathrm{A}=54 \mu \mathrm{m} ; \mathrm{B}=156 \mu \mathrm{m} ; \mathrm{C}=117 \mu \mathrm{m} ; \mathrm{D}=278 \mu \mathrm{m}$.

\section{Cephalodia on the upper cortex of mature thalli}

Small warts were frequently found on the upper cortex of mature thalli, which were composed of cyanobacterial clusters surrounded by hyphal strands (Fig. 2A \& B). This epigenic cephalodium development was found particularly in the depressions and along ridges of young lobes. Rarely, cephalodia were located on the top of the ridges or on the thallus margin. Also, infrequently, two or three adjacent mature cephalodium protuberances were found on older lobes.

Observed epigenic cephalodium formation began with local growth of the paraplectenchymatous cortex. Consequently, a small and brownish wart appeared on the upper thallus surface (Fig. 2A). Filiform hyphae grew out from this wart and enveloped cyanobacterial colonies. In specimens with more advanced stages, the mycobiont surrounded cyanobacteria with several layers of tightly packed prosoplectenchymatous hyphae. The growth of the prosoplectenchymatous tissue led to a swelling of the protuberance, which broke through the algal layer (Fig. 2B). Green algal cells lying below epigenic cephalodia were pressed downwards and expanded into the medulla. The bulb-growth also led to an enlargement of the upper cortex, the tissue characteristics of which did not differ from the surrounding thallus without cephalodia. Finally, the mature cephalodia observed enormously increased their size and were 

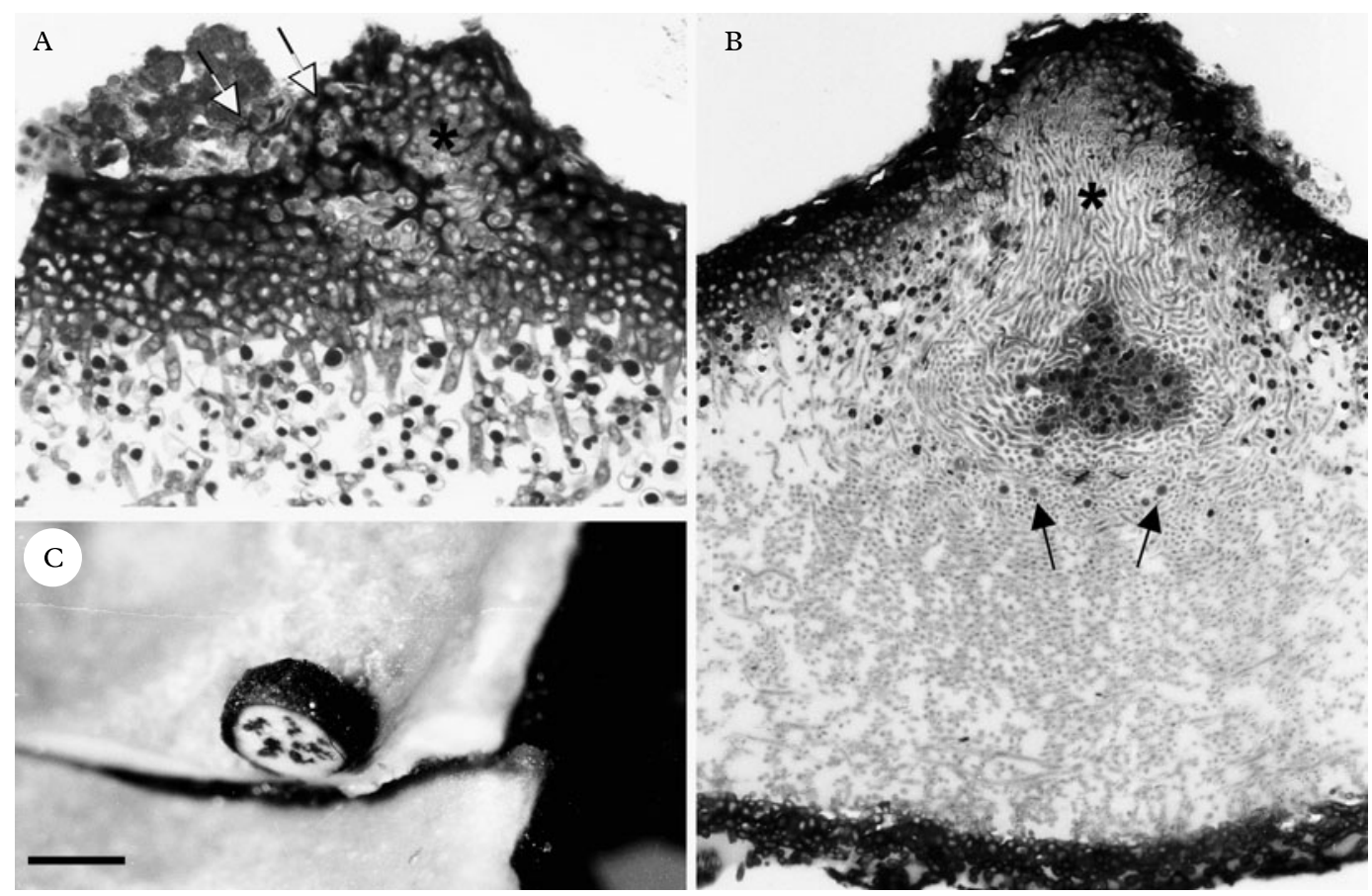

FIG. 2. The formation of cephalodia in the upper cortex of $L$. pulmonaria. A, the epigenic cephalodium development begins with local growth of the upper cortex that forms an external visible, small brownish wart (asterisk). This protuberance forms thin-walled hyphae expanding into adjacent cyanobacterial aggregates (arrows); B, the mycobiont surrounds cyanobacteria with several layers of tightly packed prosoplectenchymatous hyphae (asterisk), at this stage the green algal cells lying below the cephalodium were pressed downwards into the medulla (arrows); C, a mature superior cephalodium cut in situ by hand. Scales: $\mathrm{A}=67 \mu \mathrm{m} ; \mathrm{B}=98 \mu \mathrm{m} ; \mathrm{C}=235 \mu \mathrm{m}$.

visible as a large brownish or dark brown protuberance on the upper cortex. Within a cephalodium, cyanobacterial cells were arranged in compartments that gave the typical cerebral aspect in cross-sections (Fig. 2C). At this stage, all green algal cells below the cephalodia were squeezed flat and were possibly dead.

\section{Cephalodia on the lower cortex}

Young cephalodium stages became externally visible as small brownish protuberances and particularly originated in the concave parts of the lower cortex that were densely covered with tomentum. Normally one, rarely two or three, cephalodia matured within a fovea. However, many young cephalodia occasionally developed in close proximity. Exceptionally, cephalodia were found on thallus margins.
Cephalodia initiating on the lower cortex did not differ from those on the upper surface. Growing hyphae of the lower cortex surrounded adjacent cyanobacterial colonies. In specimens with mature cephalodia, two types of hypogenic cephalodial formation were found; hyphae either grew into the thallus (internal cephalodia) or formed a bulb outside the lower cortex (external cephalodia).

Young internal cephalodia were localized within the medulla and were visible only in cross- sections of the thallus. Thalli with immersed, olive-green or brownish spots on the upper cortex showed in cross-sections that internal cephalodia enlarged in such a way that the algal cells were shifted from their layer. In thalli with visible protuberances on the lower cortex, sometimes also on the upper surface, we found mature, internal cephalodia that had increased their size beyond the 

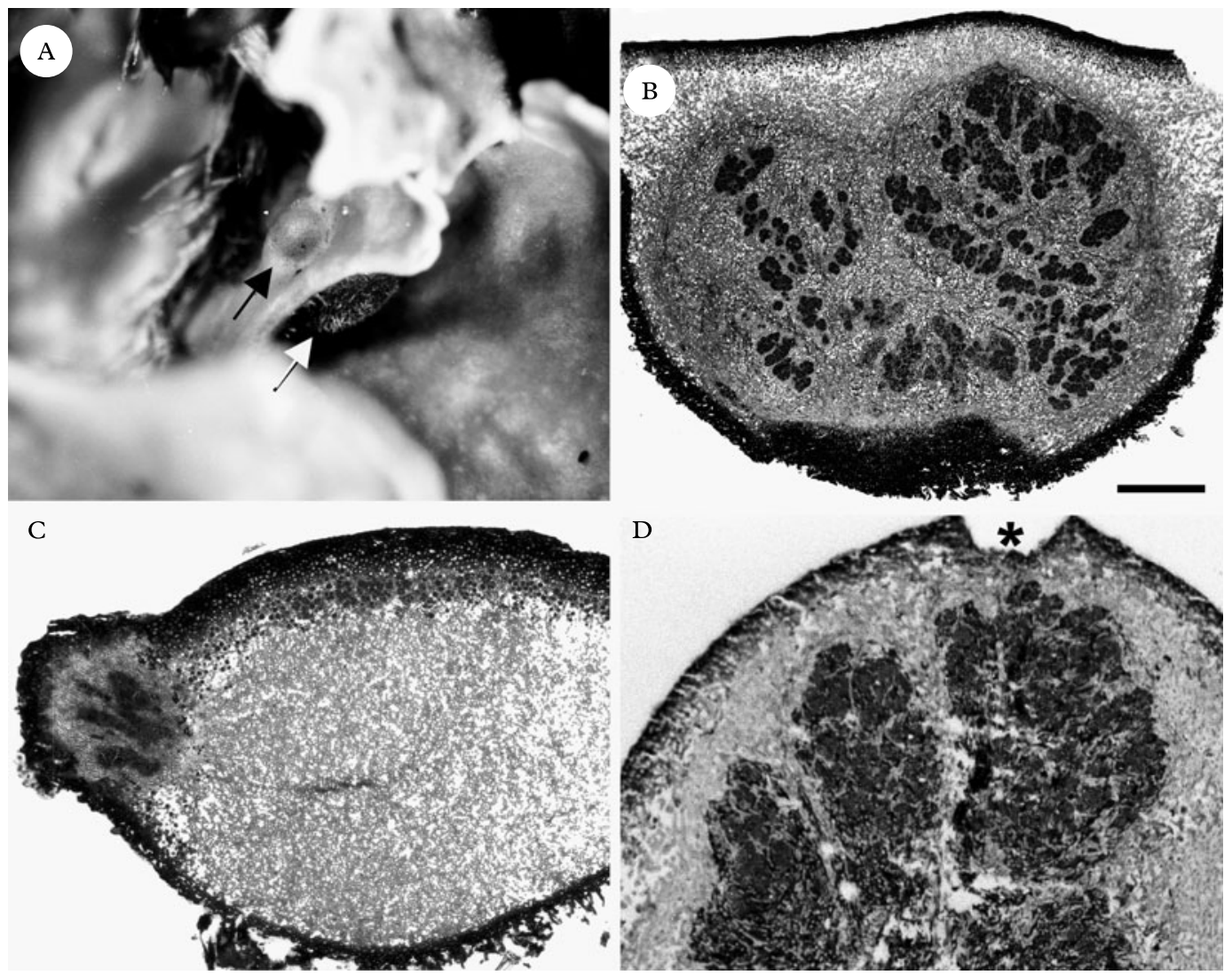

Fig. 3. Different mature cephalodia of $L$. pulmonaria. A, mature cephalodia increase their volume enormously and are visible as protuberances on the lower and/or upper thallus surface (arrows); B-D, light micrographs of diverse cephalodia. B, this cephalodium shows through its position relative to the green algal layer that it was formed externally on the lower cortex, note the interrupted green algal layer at the top of the cephalodium; C, cephalodia can also occur on the thallus margin; $\mathrm{D}$, the increasing volume leads to a distension of the upper cortex and the formation of a secondary cortex (asterisk). Scales: $\mathrm{A}=288 \mu \mathrm{m} ; \mathrm{B}=445 \mu \mathrm{m} ; \mathrm{C}=229 \mu \mathrm{m} ; \mathrm{D}=224 \mu \mathrm{m}$.

thallus thickness (Fig. 3A). Large cephalodia caused distension of the upper cortex, which broke open and was again closed by formation of a secondary cortical tissue (Fig. 3D).

External cephalodia increased their volume enormously during the maturation process and appeared as brownish or dark brown protuberances that were covered with a white tomentum (Fig. 3A). Despite the large growth of this cephalodium type, the cortex rarely ruptured and the green-algal layer was not disrupted (Fig. 3B).

\section{Discussion}

These findings show that the anchoring hyphae, the lower cortex, the upper cortex and even the apical zone of young thalli are able to form cephalodia. Moreover, these results demonstrate that the anchoring hyphae and the young thallus respond with the same phenotypic characteristics when they incorporate cyanobacteria. A similar origin of cephalodia, formed by the hypothallus and not in contact with the green-algal squamules, has been observed in Placopsis pycno- 
theca (De los Ríos et al. 2011). In this lichen species, cephalodium formation seems to run all developmental steps within the hypothallus, from hyphae encircling cyanobacteria to adult stages with several cyanobiont compartments within a cephalodium. However, not all young thalli investigated had formed cephalodia. This fact supports field observations made by Scheidegger (1995). Nevertheless, it must be considered that the anchoring hyphae have not yet been systematically searched for cephalodia. Scheidegger (1995) further observed a very low growth rate in young thalli that the author attributed to limiting light conditions at the study site. Considering the role which nitrogenous triggers may play on morphogenesis, the absence of compatible cyanobacteria on the artificial substratum (cotton gauze) could also have limited the growth of young thalli.

According to Jordan (1970), cephalodium formation in Lobaria pulmonaria is only possible on the lower cortex, and cephalodia lying on the upper cortex may develop from erupting internal cephalodia. Our observations, however, show that Nostoc cells can also be captured by hyphae of the upper cortex, and that the upper cortex itself is able to form cephalodia. In fact, the same incorporation process has been reported for the formation of isidia, at which cortical hyphae were observed to capture compatible, free-living green algae, which fall accidentally onto the thallus surface (Jahns 1988). These findings also confirm the appropriation process of epiphytic cyanobacteria by cyanotrophic lichens. These cyanotrophic associations, usually with Stigonema or Gloeocapsa species, consist of epiphytic free-living cyanobacteria that become covered by mats of fungal hyphae but do not form a marginal layer, thus are not considered to be true cephalodia (Poelt \& Mayrhofer 1988; Rikkinen et al. 2002). Obviously, parts of the upper cortex preserve a low degree of differentiation, in spite of being composed by paraplectenchymatous tissue. This fact corresponds with the multifunctionality and considerable plasticity of the upper cortex forming regenerative structures observed by Ott et al. (1993) on L. pulmonaria.
The lower green algal cells scattered in the medulla are characteristic for epigenic cephalodia. Kaule (1932) described epigenic cephalodia that shift the algal layer down the medulla. Jordan (1970) also noticed the presence of green algal cells below superior cephalodia, but the author attributed them to a partial regeneration of the green algal layer. However, based on the assumption that the mycobiont controls the positioning of green algae in a distinct layer (Honegger 1987), we consider a regeneration of the green-algal layer in the core of the medulla to be very unlikely. Henssen \& Jahns (1974) also reported on green algal cells below a superior cephalodium in L. pulmonaria but interpreted this as an exception. On the contrary, Rai \& Bergman (2002) characterized the green-algal layer below epigenic cephalodia as pressed deep into the medulla in consequence of cephalodium growth. An internal growth of epigenic cephalodia has not been observed in this study but has been described by Moreau (1921) and Henssen \& Jahns (1974). Even if the external form seems to be more frequent than the internal, no morphological criteria could be established to predict the growing direction of cephalodia. In any case, relocation of cephalodia during the maturation process was also observed in Placopsis pycnotheca, where cephalodia can stay below ground, deep within the hypothallus, or grow towards the soil surface in close neighbourhood to green-algal squamules (De los Ríos et al. 2011). Figure 4 summarizes the development phases of $L$. pulmonaria cephalodia found both in this study and described by other authors (Moreau 1921; Kaule 1932; Jordan 1970).

The position on the thallus and the vicinity to compatible Nostoc cells seem to be important for the ability to develop cephalodia. Early stages of epigenic cephalodia are usually found in young lobes, whereas in the older parts of the thallus only mature cephalodia occur. Additionally, epigenic cephalodia are formed in the depressions where more Nostoc cells live rather than on the ridges of foveae. In the same way, hypogenic cephalodia are usually found in the ribbed parts of the lower cortex, corresponding to 
Epigenic cephalodia formation
Hypogenic cephalodia formation
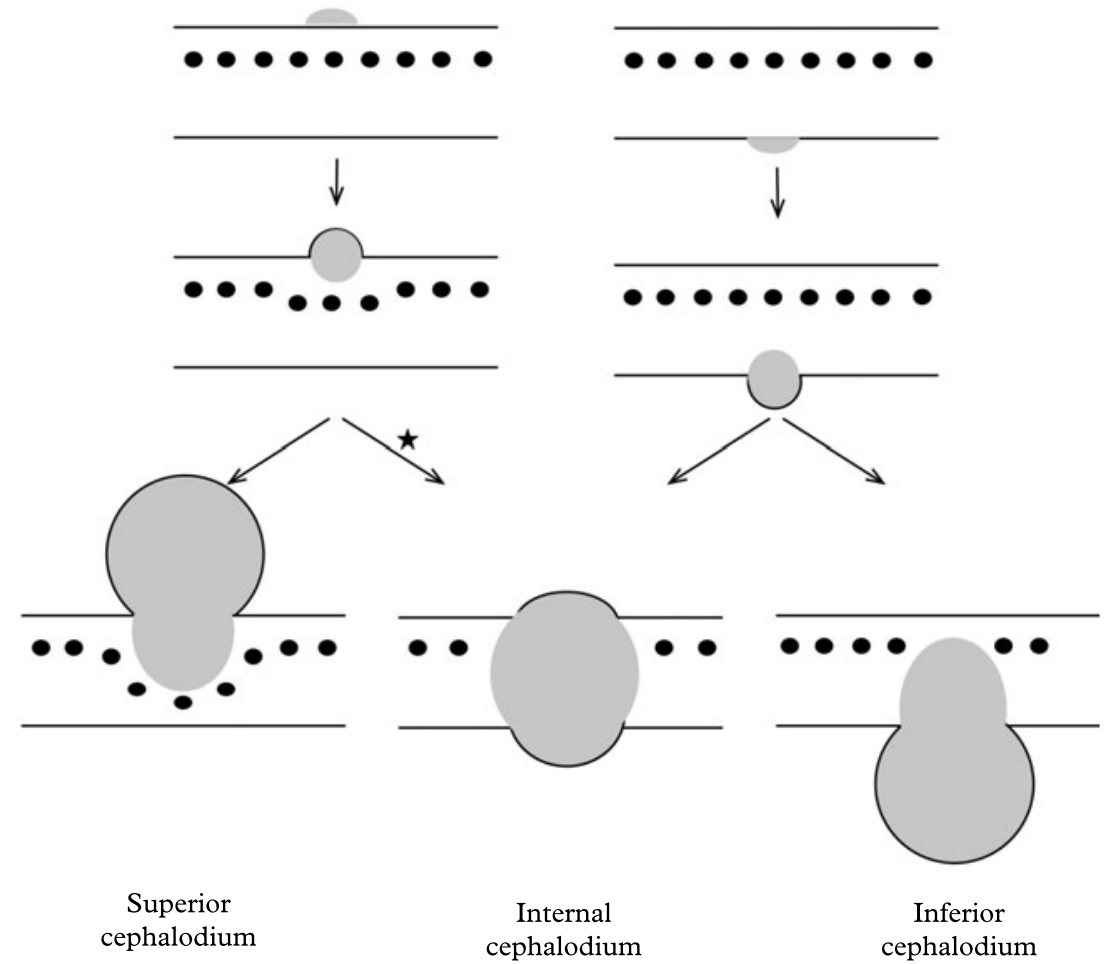

FIG. 4. Summary of cephalodial development in L. pulmonaria. While inferior cephalodia interrupt the algal layer when they increase their volume (right), the green algae scattered in the medulla are characteristic for superior cephalodia (left). (*) Developmental stages from superior cephalodia growing into the thallus were described by Moreau (1921) but were not observed in this study.

the most rhizinate areas of the thallus, where dense Nostoc colonies are found. Jensen \& Siebke (1997) studied the fluorescence of the green alga and cyanobacterium on the lower cortex of Lobaria pulmonaria specimens and observed a tendency to form external cephalodia.

Unlike cycads and bryophytes that associate with cyanobacteria in which structures are formed where Nostoc cells will be housed in the absence of the symbiont (Costa et al. 2001, 2004), cephalodia are not formed before the mycobiont has contact with freeliving cyanobacteria. Outgrowing hyphae of the uppermost cortical layer enclose Nostoc cells. The incorporation process probably begins by a chemical stimulation of hyphal growth by algal excretion, as suggested by Jordan (1970). In fact, in axenic cultivation experiments of Lobaria pulmonaria and L. laetevirens, Lallemant \& Bernard (1977) showed that green-algal extracts trigger ascospore germination and hyphal growth. Moreover, in resynthesis experiments, hyphae of Baeomyces rufus (Huds.) Rebent. grew after a few days co-culture with the compatible Elliptochloris bilobata Tschermak-Woess towards remote algal cells (Trembley et al. 2002). Subsequently it was found that lectins formed by mycobionts seemed to be involved in highly specific recognition of the compatible photobiont, as suggested for different lichen 
symbioses (Kardish et al. 1991; Elifio et al. 2000; Lehr et al. 2000; Legaz et al. 2004; Díaz et al. 2009, 2011; Feoktistov et al. 2009; Vivas et al. 2009). Lichen-forming fungi seem to be highly selective in choosing their cyanobacterial partner because only a few closely related Nostoc strains typically serve as the appropriate symbiotic partner for each fungal species (Paulsrud et al. 1998, 2000, 2001; Lohtander et al. 2003; Stenroos et al. 2006; Myllys et al. 2007; Lücking et al. 2009; Rikkinen 2009). However, Lobaria pulmonaria and Peltigera venosa are exceptions to this rule. Both species were shown to associate with a wide range of Nostoc strains (Paulsrud \& Lindblad 2002; Rikkinen et al. 2002; Myllys et al. 2007).

In conclusion, this study has demonstrated that all stages of thallus development and even very young thalli (including the anchoring hyphae) of Lobaria pulmonaria form cephalodia. In mature thalli, cephalodia are usually formed in the young parts of lobes. After contact between the mycobiont and compatible free-living cyanobacteria, cephalodia in Lobaria pulmonaria are formed during the lichen's entire life cycle, and each cephalodium formation implies a new recognition process and symbiotic interactions with a wide range of Nostoc strains. We postulate an incorporation process that involves upper and lower cortical hyphae growing out towards adjacent cyanobacterium colonies, enveloping them and incorporating them into the thallus. The result of this process is what we observe as internal cephalodia, or external cephalodia on the upper or lower cortex. Further studies, including experiments, need to be carried out to explore the role of cephalodial cyanobacteria in growth rates and the life cycle of this threatened tripartite lichen species.

Special thanks are due to Prof. Dr Rosmarie Honegger (Switzerland) for training Carolina Cornejo in microscopic techniques and for giving her insight into the fascinating life forms of lichens.

\section{REFERENCES}

Antoine, M. E. (2004) An ecophysiological approach to quantifying nitrogen fixation by Lobaria oregana. Bryologist 107: 82-87.
Benner, J. W., Conroy, S., Lunch, C. K., Toyoda, N. \& Vitousek, P. M. (2007) Phosphorus fertilization increases the abundance and nitrogenase activity of the cyanolichen Pseudocyphellaria crocata in Hawaiian montane forests. Biotropica 39: 400-405.

Büdel, B. \& Scheidegger, C. (1996) Thallus morphology and anatomy. In Lichen Biology (T. H. Nash III, ed): 24-36. Cambridge: Cambridge University Press.

Costa, J.-L., Paulsrud, P., Rikkinen, J. \& Lindblad, P. (2001) Genetic diversity of Nostoc endophytically associated with two bryophyte species. Applied and Environmental Microbiology 67: 4393-4396.

Costa, J.-L., Martinez Romero, E. \& Lindblad, P. (2004) Sequence based data supports a single Nostoc strain in individual coralloid roots of cycads. FEMS Microbiology Ecology 49: 481-487.

De los Ríos, A., Raggio, J., Pérez-Ortega, S., Vivas, M., Pintado, A., Green, T. G. A., Ascaso, C. \& Sancho, L. G. (2011) Anatomical, morphological and ecophysiological strategies in Placopsis pycnotheca (lichenized fungi, Ascomycota) allowing rapid colonization of recently deglaciated soils. Flora 206: 857864.

Díaz, E.-M., Sacristán, M., Legaz, M.-E. \& Vicente, C. (2009) Isolation and characterization of a cyanobacterium-binding protein and its cell wall receptor in the lichen Peltigera canina. Plant Signaling and Behavior 4: 598-603.

Díaz, E.-M., Vicente-Manzanares, M., Sacristán, M., Vicente, C. \& Legaz, M.-E. (2011) Fungal lectin of Peltigera canina induces chemotropism of compatible Nostoc cells by constriction-relaxation pulses of cyanobiont cytoskeleton. Plant Biology 12: 615-621.

Elifio, S. L., De Lourdes, M., Da Silva, C. C., Iacomini, M. \& Gorini, P. A. J. (2000) A lectin from the lichenized Basidiomycete Dictyonema glabratum. New Phytologist 148: 327-334.

Feoktistov, A. S., Kitashov, A. V. \& Lobakova, E. S. (2009) The characterization of lectins from the tripartite lichen Peltigera aphthosa (L.) Willd. Moscow University Biological Sciences Bulletin 64: 23-27.

Forsell, K. B. J. (1884) Lichenologische Untersuchungen: Ueber die Cephalodien. Flora 67: 1-8, 33-46, 58-63, 177-187.

Green, T. G. A., Horstmann, J., Bonnett, H., Wilkins, A. \& Silvester, W. B. (1980) Nitrogen fixation by members of the Stictaceae (lichenes) of New Zealand. New Phytologist 84: 339-348.

Green, T. G. A., Schlensog, M., Sancho, L. G., Winkler, J. B., Broom, F. D., Schroeter, B. (2002) The photobiont determines the pattern of photosynthetic activity within a single lichen thallus containing cyanobacterial and green algal sectors (photosymbiodeme). Oecologia 130: 191-198.

Guzman, G., Quilhota, W. \& Galloway, D. J. (1990) Decomposition of species of Pseudocyphellaria and Sticta in a southern Chilean forest. Lichenologist 22: 325-331.

Hawksworth, D. L. \& Hill, D. J. (1984) The Lichen-forming Fungi. Glasgow and London: Blackie \& Son Ltd.

Henssen, A. \& Jahns, H. M. (1974) Lichenes. Stuttgart: Thieme Verlag. 
Honegger, R. (1987) Questions about pattern formation in the algal layer of lichens with stratified (heteromerous) thalli. Bibliotheca Lichenologica 25: 59-71.

Honegger, R. (2001) The symbiotic phenotype of lichen-forming Ascomycetes. In The Mycota IX. (B. Hock, ed): 165-188. Berlin, Heidelberg: SpringerVerlag.

Hue, M. L'abbé (1904) Description de deux espèces de lichens et de céphalodies nouvelles: Céphalodies. Extrait des annals de l'association des naturalistes de Levallois-Perret 10: 37-41.

Jahns, H. M. (1988) The lichen thallus. In CRC Handbook of Lichenology (M. Galun, ed.): 95-143. Boca Raton, Florida: CRC Press.

Jensen, M. \& Siebke, K. (1997) Fluorescence imaging of lichens in the macro scale. Symbiosis 23: 183-196.

Jordan, W. P. (1970) The internal cephalodia of the genus Lobaria. Bryologist 73: 669-681.

Kardish, N., Silberstein, L., Flemminger, N. \& Galun, M. (1991) Lectin from the lichen Nephroma laevigatum Ach. Localization and function. Symbiosis 11: 47-62.

Kaule, A. (1932) Die Cephalodien der Flechten. Flora 126: $1-44$.

Knops, J. M., Nash III, T. H., Boucher, V. L. \& Schlesinger, W. H. (1991) Mineral cycling and epiphytic lichens: implications at the ecosystem level. Lichenologist 23: 309-321.

Knowles, R. D., Pastor, J. \& Biesboer, D. D. (2006) Increased soil nitrogen associated with dinitrogenfixing, terricolous lichens of the genus Peltigera in northern Minnesota. Oikos 114: 37-48.

Lallemant, R. \& Bernard, T. (1977) Obtention de cultures pures des mycosymbiotes du Lobaria laetevirens (Lightf.) Zahlbr. et du Lobaria pulmonaria (L.) Hoffm.: le role des gonidies. Revue Bryologique et Lichenologique 43: 303-308.

Lawrey, J. D. (1986) Biological role of lichen substances. Bryologist 89: 111-122.

Legaz, M.-E., Fontaniella, B., Millanes, A.-M. \& Vicente, C. (2004) Secreted arginases from phylogenetically far-related lichen species act as cross-recognition factors for two different algal cells. European fournal of cell biology 83: 435-446.

Lehr, H., Galun, M., Ott, S., Jahns, H.-M. \& Fleminger, G. (2000) Cephalodia of the lichen Peltigera aphthosa (L.) Willd. Specific recognition of the compatible photobiont. Symbiosis 29: 357-365.

Lohtander, K., Oksanen, I. \& Rikkinen, J. (2003) Genetic diversity of green algal and cyanobacterial photobionts in Nephroma (Peltigerales). Lichenologist 35: 325-329.

Lücking, R., Lawry, J. D., Sikaroodi, M., Gillevet, P. M., Chaves, J. L., Sipman, H. J. M. \& Bungartz, F. (2009) Do lichens domesticate photobionts like farmers domesticate crops? Evidence from a previously unrecognized lineage of filamentous cyanobacteria. American fournal of Botany 96: 1409-1418.

Miądlikowska, J. \& Lutzoni, F. (2000) Phylogenetic revision of the genus Peltigera (lichen-forming Ascomycota) based on morphological, chemical, and large subunit nuclear ribosomal DNA data. International fournal of Plant Science 161: 925-958.

Miądlikowska, J. \& Lutzoni, F. (2004) Phylogenetic classification of peltigeralean fungi (Peltigerales, Ascomycota) based on ribosomal RNA small and large subunits. American fournal of Botany 91: 449464.

Moreau, M. F. (1921) Recherches sur les lichens de la famille des Stictacées. Annales des Sciences Naturelles. Botanique, Dixiéme Série, 3: 297-374.

Myllys, L., Stenroos, S., Thell, A. \& Kuusinen, M. (2007) High cyanobiont selectivity of epiphytic lichens in old growth boreal forest of Finland. New Phytologist 173: 621-629.

Nylander, W. (1868) Circa cephalodia simul epigena et hypogena. Flora 51: 372-373.

Ott, S., Treiber, K. \& Jahns, H.-M. (1993) The development of regenerative thallus structures in lichens. Botanical Fournal of the Linnean Society 113: 61-76.

Paulsrud, P. \& Lindblad, P. (2002) Fasciclin domain proteins are present in Nostoc symbionts of lichens. Applied and Environmental Microbiology 68: 20362039.

Paulsrud, P., Rikkinen, J. \& Lindblad, P. (1998) Cyanobiont specificity in some Nostoc-containing lichens and a Peltigera aphthosa photosymbiodeme. New Phytologist 139: 517-524.

Paulsrud, P., Rikkinen, J. \& Lindblad, P. (2000) Spatial patterns of photobiont diversity in some Nostoccontaining lichens. New Phytologist 146: 291-299.

Paulsrud, P., Rikkinen, J. \& Lindblad, P. (2001) Field experiments on cyanobacterial specificity in Peltigera aphthosa. New Phytologist 152: 117-123.

Poelt, J. \& Mayrhofer, H. (1988) Über Cyanotrophie bei Flechten. Plant Systematics and Evolution 158: 265281.

Rai, A. N. \& Bergman, B. (2002) Cyanolichens. Biology and Environment: Proceedings of the Royal Irish Academy 102: 19-22.

Rikkinen, J. (2009) Relations between cyanobacterial symbionts in lichens and plants. Microbiology Monographs 8: 265-270.

Rikkinen, J., Oksanen, I. \& Lohtander, K. (2002) Lichen guilds share related cyanobacterial symbionts. Science 297: 357.

Scheidegger, C. (1995) Early development of transplanted isidioid soredia of Lobaria pulmonaria in an endangered population. Lichenologist 27: 361-374.

Scheidegger, C., Clerc, P., Dietrich, M., Frei, M., Groner, U., Keller, C., Roth, I., Stofer, S. \& Vust, M. (2002) Rote Liste der gefährdeten baum- und erdbewohnenden Flechten der Schweiz. Bern: WSL, CJB, BUWAL.

Stenroos, S., Högnabba, F., Myllys, L., Hyvönen, J. \& Thell, A. (2006) High selectivity in symbiotic associations of lichenized ascomycetes and cyanobacteria. Cladistics 22: 230-238.

Stocker-Wörgötter, E. (1994) Artificial resynthesis of the photosymbiodeme Peltigera leucophlebia under laboratory conditions. Cryptogamic Botany 4: 300308 . 
Stocker-Wörgötter, E. (1995) Experimental cultivation of lichens and lichen symbiosis. Canadian fournal of Botany 73: 579-589.

Stocker-Wörgötter, E. (2001) Experimental studies of the lichen symbiosis: DNA-analysis, differentiation and secondary chemistry of selected mycobionts, artificial resysthesis of two- and tripartite symbiosis. Symbiosis 30: 207-227.

Sundberg, B., Näsholm, T. \& Palmqvist, K. (2001) The effect of nitrogen on growth and key thallus components in the two tripartite lichens, Nephroma arcticum and Peltigera aphtosa. Plant, Cell and Environment 24: 517-527.
Trembley, M. L., Ringli, C. \& Honegger, R. (2002) Morphological and molecular analysis of early stages in the resynthesis of the lichen Baeomyces rufus. Mycological Research 106: 768-776.

Vivas, M., Sacristán, M., Legaz, M. E. \& Vicente, C. (2009) The cell recognition model in chlorolichens involving a fungal lectin binding to an algal ligand can be extended to cyanolichens. Plant Biology 12: 615-621.

Winter, G. (1877) Lichenologische Notizen: Cephalodien von Sticta und Solorina. Flora 60: 177-203, 193-203. 